Part of Journal of Research of the National Bureau of Standards, Volume 15, July 1935

\title{
INFLUENCE OF SULPHONATED COD-LIVER OIL ON THE DETERIORATION OF VEGETABLE-TANNED LEATHERS BY SULPHURIC ACID
}

\author{
By Everett L. Wallace, Charles L. Critchfield, and John Beek, Jr.
}

\section{ABSTRACT}

The deterioration by sulphuric acid of leather containing 10 percent of sulphonated cod-liver oil was compared with that of leather containing no sulphonated oil. It was found that the addition of oil did not protect the leather from the effect of the acid. The addition of oil apparently increased the effect of the acid on the leather tanned with chestnut-wood extract. All of the leather which had a $\mathrm{pH}$ less than 3.0 showed deterioration after 2 years' aging.

I. Introduction

II. Materials and methods used

III. Results_...

IV. Summary

\section{INTRODUCTION}

An extended study of the effect of sulphuric acid on leather has been in progress at the National Bureau of Standards for about 8 years. The object has been to determine the influence of various factors on the deterioration of leather by acid. It was shown ${ }^{1}$ that the addition of 20 percent of a mixture of equal parts of beef tallow and cod-liver oil has no significant effect on the deterioration of leather by sulphuric acid. The present phase of the investigation was undertaken in order to determine the influence of the addition of sulphonated cod-liver oil on the effect of sulphuric acid on leather.

\section{MATERIALS AND METHODS USED}

Two lots of five hides each were used to prepare the leather. The tanning process was carried out in the experimental tannery at this Bureau, one lot being tanned with chestnut-wood extract, the other with quebracho-wood extract. The results of the analysis of the leathers before treatment are given in table 1. The official methods of the American Leather Chemists Association were used for the analyses, except for the total sulphur, which was determined by a nitric-acid-bromine-oxidation method. ${ }^{2}$

$1 \mathrm{~J}$. Am. Leather Chem. Assn. 25, 667 (1931).

8 J. Am. Leather Chem. Assn. 26, 444 (1931). 
TABLE 1.-The chemical analyses of leathers before treatment

[The results are expressed as percentage of the leather, excepted for degree of tannage and $\mathrm{pH}$ ]

\begin{tabular}{|c|c|c|}
\hline Tanning material & Chestnut & Quebracho \\
\hline $\begin{array}{l}\text { Water-soluble- } \\
\text { Hide substance- } \\
\text { Grease (petroleum-ether extract) } \\
\text { Moisture } \\
\text { Insoluble ash. } \\
\text { Combined tannin }{ }^{1}\end{array}$ & $\begin{array}{r}7.67 \\
50.15 \\
4.18 \\
10.66 \\
0.10 \\
27.24\end{array}$ & $\begin{array}{r}9.00 \\
47.93 \\
3.14 \\
9.93 \\
0.10 \\
29.90\end{array}$ \\
\hline Total. & 100.00 & 100.00 \\
\hline $\begin{array}{l}\text { Degree of tannage }{ }^{2} \\
\text { Soluble tannins } \\
\text { Soluble nontannins } \\
\text { Total ash } \\
\text { Total sulphur }\left(\text { as } \mathrm{H}_{2} \mathrm{SO}_{4} \text { ) }\right. \\
\mathrm{pH}^{3} \text { (glass electrode) }\end{array}$ & $\begin{array}{l}54 \\
6.31 \\
1.36 \\
0.26 \\
0.14 \\
4.18\end{array}$ & $\begin{array}{l}62 \\
7.68 \\
1.32 \\
0.16 \\
0.10 \\
5.45\end{array}$ \\
\hline
\end{tabular}

1 Determined by difference.

2 The ratio of combined tannin to hide substance.

$84.9 \mathrm{~g}$ of dry leather in $100 \mathrm{ml}$ of distilled water.

The sulphonated cod-liver oil was a commercial product, containing 2.08 percent of sulphur, calculated as sulphuric acid, 2.3 percent of ash, and 8.2 percent of water. The oil was ammonia neutralized.

The distribution of the leather relative to hide location, for the treatment with acid and oil, was like that previously described, ${ }^{3}$ except that each value of deterioration reported is calculated from the average of 30 samples instead of 42 . The amounts of acid added were approximately $0,1,2$, and 3 percent. After the acid treatment, one-half of the leather was oiled with sulphonated cod-liver oil. Each test block was weighed and the oil at $40^{\circ} \mathrm{C}$ was rubbed into the leather until the gain in weight indicated an oil content of 10 percent. The results of the total sulphur and $\mathrm{pH}$ determinations on the treated leather are given in table 2.

The leather was aged at a temperature of $70^{\circ} \mathrm{F}$ and a relative humidity of 65 percent. Samples for the determination of tensile strength were taken $0,6,12,18$, and 24 months after treatment.

\section{RESULTS}

The quantity used as a criterion of deterioration is the ratio of the average tensile strength of a group of aged samples to the average tensile strength of the corresponding group before treatment. Table 2 shows these ratios for the five aging periods. The results for the 24 months' aging period are shown in graph A, figure 1, plotted against the $\mathrm{pH}$ of the leather before aging.

\footnotetext{
8. Research NBS 14, 121 (1935) RP761 and J. Am. Leather Chem. Assn. 30, 91 (1935).
} 
TABLE 2.-The analysis of the treated leather and the results of the determinations of the relative tensile strength

CHESTNUT

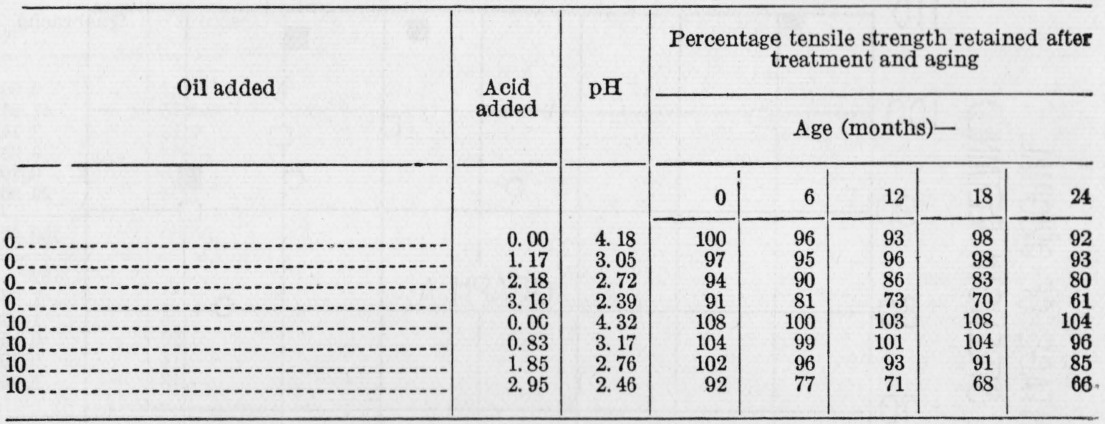

QUEBRACHO

\begin{tabular}{|c|c|c|c|c|c|c|c|}
\hline 10 & $\begin{array}{l}0.00 \\
0.88 \\
1.54 \\
2.42 \\
0.00 \\
0.85 \\
1.43 \\
2.20\end{array}$ & $\begin{array}{l}5.45 \\
3.55 \\
2.98 \\
2.54 \\
5.58 \\
3.68 \\
3.07 \\
2.53\end{array}$ & $\begin{array}{r}98 \\
95 \\
101 \\
96 \\
107 \\
101 \\
108 \\
103\end{array}$ & $\begin{array}{r}97 \\
98 \\
99 \\
96 \\
103 \\
100 \\
106 \\
98\end{array}$ & $\begin{array}{r}95 \\
99 \\
97 \\
92 \\
105 \\
100 \\
105 \\
99\end{array}$ & $\begin{array}{r}100 \\
104 \\
101 \\
93 \\
103 \\
106 \\
108 \\
97\end{array}$ & $\begin{array}{r}99 \\
98 \\
97 \\
90 \\
109 \\
108 \\
107 \\
93\end{array}$ \\
\hline
\end{tabular}

As the addition of oil increased the tensile strength of the leather, a direct comparison of the leathers, with and without oil, shows not only the influence of the oil on the deterioration of the leather by acid, but also the effect of the oil on the leather. In order to make a proper comparison of the leathers, the relative tensile strengths given in table 2 were reduced to a common basis by subtracting the values for the leather containing no added acid from the other values in the same group with respect to oil treatment and aging period. Taking the chestnut leather without added oil for example, the figure 92 was subtracted from each of the values given for the 24 months' period. The resulting corrected values show the effect of the acid on the tensile strength of the leather. The results for the 24 months' aging period are shown in graph $\mathrm{B}$, figure 1, plotted against the $\mathrm{pH}$ of the leather.

There is apparently a difference between the two kinds of leather with respect to the effect of the oil on their deterioration by acid. Graph A, figure 1, shows that the chestnut leather containing acid was not improved with respect to its deterioration by acid by the addition of oil except as a result of the increase of the $\mathrm{pH}$. That is, after 24 months' aging, the leather containing added oil was no better than that to which no oil was added. In contrast to this, the quebracho leather containing added oil and acid was considerably stronger after 24 months' aging than that containing no added oil. This difference is shown also in graph B, where the effect of the acid on the chestnut leather containing oil appears to be greater than on the other leather. Although the appearance of this effect may be a result of experimental error, it does not seem probable that this is the case, as a direct comparison of the tensile strengths of the oiled and unoiled chestnut leather gives the same indication for the 12, 18, and 24 months' aging 
periods. However, it is certain that the oil did not decrease the effect of the acid on either the chestnut or quebracho leather.

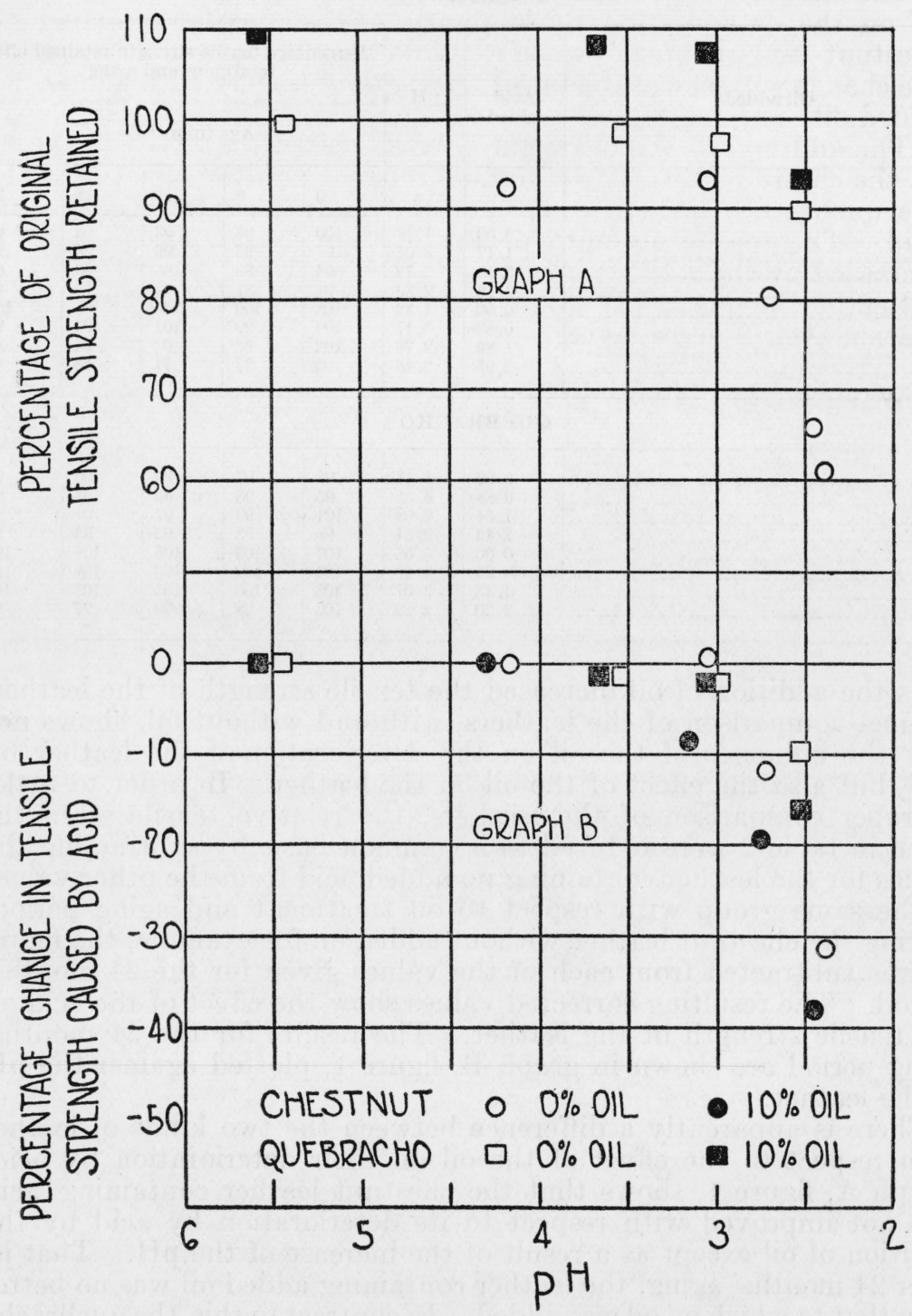

FIGURE 1.-Results of the 24 months' aging tests plotted against the $\mathrm{pH}$ of the leather before aging

It should be noticed that in no case did a sample with a $\mathrm{pH}$ lower than 3.0 before aging retain its original tensile strength, after aging 2 years. This is in accordance with previous findings in this study. ${ }^{4}$

tJ. Research NBS 14 (1935) RP761. J. Am. Leather Chem. Assn. 30, 91 (1935). 


\section{SUMMARY}

The influence of the addition of 10 percent of sulphonated cod-liver oil on the deterioration by sulphuric acid of leathers tanned with chestnut- and quebracho-wood extracts was determined by comparing the change with age of the tensile strength of leather with and without added oil.

The addition of the oil apparently increased the effect of the acid on the chestnut leather. It had no influence on the effect of acid on the quebracho leather, except for the sample containing the most acid. The tensile strength of the leather containing no acid was increased by the addition of oil.

Leather having a $\mathrm{pH}$ lower than 3.0 before aging showed deterioration after 2 years' aging.

Washington, May 15, 1935. 